\title{
Homeobox Protein MSX-1
}

National Cancer Institute

\section{Source}

National Cancer Institute. Homeobox Protein MSX-1. NCI Thesaurus. Code C40968.

Homeobox protein MSX-1 (297 aa, $31 \mathrm{kDa}$ ) is encoded by the human MSX1 gene. This protein plays a role in transcriptional modulation and odontogenesis. 